\title{
Technical Study Of Bolok Crossing Port Terminal In Kupang District - East Nusa Tenggara
}

\author{
Anie A Tuati ${ }^{1, *}$, Deasi D. A. A. Daud ${ }^{1}$, Amy Wadu ${ }^{1}$ \\ \{adrianti.tuati@gmail.com,", deasi.daud@gmail.com,awd.ub15@gmail.com\} \\ Civil Engineering Department, State Polytechnic of Kupang, Adisucipto Street, Penfui, Kupang, \\ Indonesia $^{1}$
}

\begin{abstract}
Bolok crossing port is one of the passenger ports that serves as a means of supporting sea transportation going to or coming from Kupang District.In this study the data collection technique used was a qualitative method by observing and interviewing directly to informants using Bolok Crossing port services and quantitative methods by taking primary data, namely questionnaires and secondary data collection obtained from the Department of Transportation (ASDP). This study used the Importance Performance Analysis (IPA) and Customer Satisfaction Index (CSI) methods. The results showed that there were factors influencing the assessment of service users towards the Bolok Crossing Port service for transport passenger service users and transport crew service users and the perception of service users (transport passengers) and the perception of the service crew transport/driver (vehicle transport) visitors to the Port of Crossing Bolok
\end{abstract}

Keywords: Service Quality, Passenger, Transportation Crew (driver), Importance Performance Analysis, Customer Satisfaction Index

\section{Introduction}

Bolok Ferry Port is a passenger port that serves as a means of supporting sea transportation going to or coming from Kupang District. Bolok Ferry Port plays an important role, one of which is to help the smooth rotation of regional trade wheels (inter-island) such as the delivery of goods, agricultural products, livestock products from Rote island to Timor island (Kupang city), and from Alor Island to Timor Island (Kupang city) or vice versa and / to several other islands. However, in carrying out daily service activities at the Bolok port terminal, there are some problems that are often experienced by some service users of broken provided such as uncomfortable and dirty waiting rooms, the number of seats, the condition of untreated toilets (dirty), departures that are sometimes not on time, there is not health service rooms, nonfunctioning lighting, and the absence of smoking area, so it is very uncomfortable in the terminal room.

\section{Research Methods}

\subsection{Research Stages}

The stages of the study began with initial observations, data collection, data processing and analysis, up to conclusions and suggestions. This research started from identifying the 
problems that occured after making direct observations in the study area. It was carried out to determine the problems occured in the study area. The study area and the scope of the problem to be discussed were also limited. The analysis phase was a follow-up after the data processing had been completed. The purpose of this stage was to understand and to analyze the results of data processing in depth. Analysis were performed with the Validity and Reliability Test of the Quality, Importance Performance Analysis (IPA) and Customer Satisfaction Index (CSI).

\subsection{Data Collection}

There were 4 stages in data collecting method, the first stage was interviewing, that is the data collecting method by asking and answer the questions. The second stage was questionnaire, this is the data collecting method by arranging the question list or questionnaire to the respondent in writing, so it is easy to process the data. The third stage was literature study and the last one was research Instrument, the research instrument used in the form of a list of questions or questionnaire consisting of 14 questions about the importance of service quality at the port terminal and 16 questions about the performance of service quality at the port terminal.

\section{Results and Discussion}

\subsection{Validity and Reliability Test}

A. Test results for validity and reliability of Bolok Crossing Port Terminal services for transport Passengers

1). Test of validity and reliability of Bolok Crossing Terminal Service quality

Test of validity and reliability using the SPSS 17.0 program with a total of 100 respondents and the value of $r$ tables sought at the significance of 0.05 with a 2 -sided test then obtained $r$ table $=0.197$ can be seen by comparing the value of Corrected Item Total Correlation as $r$ count value. The question item is said to be valid if the value of $r$ count is greater than the value of $r$ table and if the Alpha value is greater than 0.60 then the question construct that becomes the variable dimension is reliable (Sujarweni, 2007).

Table 1. The Test of Validity of Terminal Services Quality Assessment Bolok crossing port

\begin{tabular}{|c|c|c|c|}
\hline The Symbol & r arithmetic & r table & Description \\
\hline b1 & 0,342 & 0,197 & Valid \\
\hline b2 & 0,331 & 0,197 & Valid \\
\hline b3 & 0,346 & 0,197 & Valid \\
\hline b4 & 0,502 & 0,197 & Valid \\
\hline b5 & 0,223 & 0,197 & Valid \\
\hline b6 & 0,236 & 0,197 & Valid \\
\hline b7 & 0,852 & 0,197 & Valid \\
\hline b8 & 0,552 & 0,197 & Valid \\
\hline
\end{tabular}


The results of the validity test in Table 1, show that all items for the service quality variable correlation value is greater than 0.197 so it is considered valid and can be included in the next analysis process. Likewise, the Cronbach's Alpha value for the question of terminal service quality is $0.814>0.60$, so overall the measuring instrument is said to be reliable or already has reliable internal consistency.

2). Test the validity and reliability of the importance assessment of the Bolok Crossing Port Terminal Service

Table 2. The Test of Validity of the Assessment of the Interest in Terminal Services Bolok crossing port

\begin{tabular}{|c|c|c|c|}
\hline The Symbol & r arithmetic & $\mathrm{r}$ table & Description \\
\hline $\mathrm{c1}$ & 0,343 & 0,197 & Valid \\
\hline $\mathrm{c} 2$ & 0,760 & 0,197 & Valid \\
\hline $\mathrm{c3}$ & 0,702 & 0,197 & Valid \\
\hline $\mathrm{c} 4$ & 0,503 & 0,197 & Valid \\
\hline $\mathrm{c5}$ & 0,508 & 0,197 & Valid \\
\hline $\mathrm{c6}$ & 0,346 & 0,197 & Valid \\
\hline $\mathrm{c} 7$ & 0,430 & 0,197 & Valid \\
\hline $\mathrm{c} 8$ & 0,503 & 0,197 & Valid \\
\hline
\end{tabular}

The results of the validity test in Table 2 , show that all questions for the service quality variable correlation value is greater than 0.197 so it is considered valid and can be included in the next analysis process. Likewise, the Cronbach's Alpha value for the question of terminal service quality is $0.833>0.60$, so overall the measuring instrument is said to be reliable or already has reliable internal consistency.

B. The test results for validity and reliability of Bolok Crossing Harbor Terminal services for transport Passengers (drivers)

1). The test of validity and reliability of Bolok Crossing Terminal Service quality

The test of validity and reliability using the SPSS 17.0 program with a total of 100 respondents and the value of $r$ tables sought at the significance of 0.05 with a 2 -sided test then obtained $r$ table $=0.197$ can be seen by comparing the value of Corrected Item Total Correlation as $r$ count value. The question item is said to be valid if the value of $r$ count is greater than the value of $r$ table and if the Alpha value is greater than 0.60 then the construct of the question that becomes the variable dimension is reliable (Sujarweni, 2007).

Table 3. The Test of Validity of Terminal Services Quality Assessment Bolok Ferry Port

\begin{tabular}{|c|c|c|c|}
\hline The Symbol & $\mathrm{r}$ arithmetic & $\mathrm{r}$ table & Description \\
\hline $\mathrm{d} 1$ & 0,342 & 0,197 & Valid \\
\hline $\mathrm{d} 2$ & 0,331 & 0,197 & Valid \\
\hline
\end{tabular}




\begin{tabular}{|c|c|c|c|}
\hline $\mathrm{d} 3$ & 0,346 & 0,197 & Valid \\
\hline $\mathrm{d} 4$ & 0,502 & 0,197 & Valid \\
\hline $\mathrm{d} 5$ & 0,223 & 0,197 & Valid \\
\hline $\mathrm{d} 6$ & 0,236 & 0,197 & Valid \\
\hline $\mathrm{d} 7$ & 0,852 & 0,197 & Valid \\
\hline
\end{tabular}

The results of the validity test in Table 3, show that all items for the service quality variable correlation value is greater than 0.197 so it is considered valid and can be included in the next analysis process. Likewise, the Cronbach's Alpha value for the question of terminal service quality is $0.768>0.60$, so overall the measuring instrument is said to be reliable or already has reliable internal consistency.

2). The test of validity and reliability of the importance assessment of the Bolok Crossing Port Terminal Service

Table 4. The test of Validity of the Assessment of the Interest in Terminal Services Bolok crossing port

\begin{tabular}{|c|c|c|c|}
\hline $\begin{array}{c}\text { The } \\
\text { Symbol }\end{array}$ & r arithmetic & r table & Description \\
\hline e1 & 0,810 & 0,197 & Valid \\
\hline e2 & 0,561 & 0,197 & Valid \\
\hline e3 & 0,436 & 0,197 & Valid \\
\hline e4 & 0,962 & 0,197 & Valid \\
\hline e5 & 0,980 & 0,197 & Valid \\
\hline e6 & 0,960 & 0,197 & Valid \\
\hline e7 & 0,960 & 0,197 & Valid \\
\hline
\end{tabular}

\subsection{Analysis of Importance-Performance Analysis (IPA)}

a. The importance and performance of the Terminal according to the Passenger Transport

To put each variable in the IPA diagram in the quadrant, it is calculated from each variable for both significance and performance with the results of table 5 .

Table 5. The Mean Importance-Performance Analysis (IPA) according To Passenger Transport

\begin{tabular}{|c|l|c|c|}
\hline No & \multicolumn{1}{|c|}{ Variable } & Mean Importance & Mean Performance \\
\hline 1 & $\begin{array}{l}\text { Other Port Terminal facilities have met } \\
\text { expectations (such as: toilets, waiting } \\
\text { rooms, prayer rooms, kiosks, } \\
\text { temperature control facilities (AC.fans) } \\
\text { and others) }\end{array}$ & 470 & 178 \\
\hline
\end{tabular}




\begin{tabular}{|c|c|c|c|}
\hline 2 & $\begin{array}{l}\text { The port terminal provides information } \\
\text { on the availability of emergency rescue } \\
\text { equipment in danger (fire, accident or } \\
\text { natural disaster) and health facilities for } \\
\text { emergency treatment }\end{array}$ & 403 & 361 \\
\hline 3 & $\begin{array}{l}\text { Bolok Crossing Harbor Terminal } \\
\text { provides information conveyed inside } \\
\text { the terminal to service users regarding } \\
\text { estimated time of arrival and departure } \\
\text { of the ship }\end{array}$ & 406 & 409 \\
\hline 4 & $\begin{array}{l}\text { The Port Terminal Officer gives you } \\
\text { good service if there are problems with } \\
\text { the Terminal facilities }\end{array}$ & 408 & 392 \\
\hline 5 & $\begin{array}{l}\text { The port terminal has applicable } \\
\text { regulations }\end{array}$ & 469 & 469 \\
\hline 6 & $\begin{array}{l}\text { The port terminal is always under the } \\
\text { supervision of internal parties (security } \\
\text { officers) }\end{array}$ & 394 & 394 \\
\hline 7 & $\begin{array}{l}\text { The Port Terminal has good and } \\
\text { effective parking regulations to create a } \\
\text { smooth flow }\end{array}$ & 426 & 386 \\
\hline 8 & $\begin{array}{l}\text { The Passenger Terminal provides a } \\
\text { room or a special place for nursing } \\
\text { mothers }\end{array}$ & 433 & 375 \\
\hline
\end{tabular}

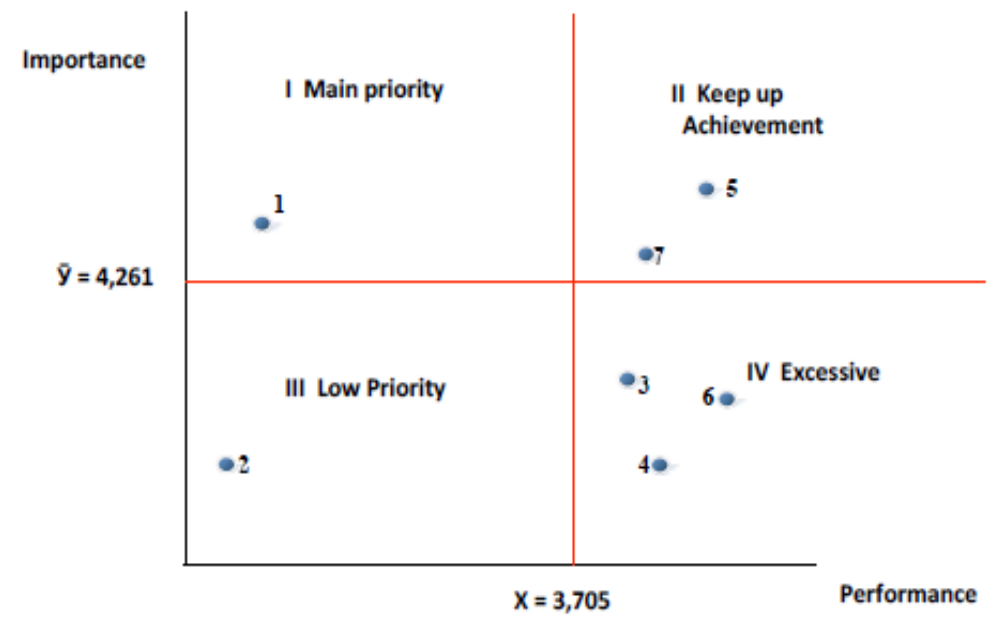

Figure 1. The Importance-Performance Analysis (IPA) Diagram results according to Passenger Transportation

The explanation for each quadrant is as follows:

I. First Quadrant (main priority)

There is one factor that is located in this quadrant, that is the other Port Terminal Facilities, they have met expectations (such as: toilets, waiting rooms, praying rooms, kiosks, air conditioning facilities, fans and others). This means that port terminal service users are not 
satisfied with the service quality of the factors, thus demanding an effort to improve service quality.

Other Port Terminal facilities have not met expectations (such as toilets, waiting rooms, praying rooms, kiosks, air conditioning facilities, fans, etc.) because the waiting rooms and toilets that available at Bolok terminal port are not comfortable because they look unclean The praying facilities are also not available at the Bolok terminal, so for the Moslems, they cannot pray if they are at the port terminal and also the existing kiosks are less neatly arranged.

\section{Second Quadrant (keep up achievement)}

There are 3 factors of port terminal services that successfully occupy this quadrant that is the port terminal has got applicable regulations, the Port Terminal has good and effective parking regulations to realize a smooth flow and the Passenger Terminal provides a room or a special place for breastfeeding mothers. According to respondents, the Port Terminal has got regulations in which several places have regulations that must be implemented while at the port so that the passengers feel safe while at the port terminal. The Port Terminal has good and effective parking regulations to create a smooth flow in conditions of heavy traffic, according to respondents, the existing parking terminals are good, so far the traffic flow is smooth, there is no traffic jam, because there are always officers who regulate traffic flow well.

III. Third Quadrant (low priority)

There is one factor in port terminal services that occupies this quadrant and has low priority to be carried out, that is the port terminal provides information on the availability of emergency rescue equipment in danger (fire, accident or natural disaster) and health facilities for emergency treatment. According to respondents they pay less attention to this factor because when the sick passengers, they prefer to take action on their own treatment directly.

IV. Fourth Quadrant (excessive)

There are three factors that get over-assessment from respondents, that are Bolok Crossing Harbor Terminal provides information delivered in the terminal to the service user regarding estimated time of arrival and departure of the ship, the Port Terminal Officer gives you good service if there are problems with the Terminal facilities and the Port Terminal always under the supervision of internal parties (security officers). According to respondents there is always information about the arrival and departure of the ship, both when the ship that wants to be boarded does not depart according to the specified schedule, this information is obtained from some social media so that respondents who wish to depart that day do not have to go to the port. And so far the officers at the port of the police have always been on standby at their respective guard posts and at several points to maintain security and expedite the flow of traffic at the port.

b. The importance and performance of the Terminal according to the Transportation Crew (Driver)

To place each variable in the IPA diagram in the quadrant, it is calculated from each variable for both significance and performance with the results of Table 6.

Table 6. The Mean Importance-Performance Analysis (IPA) according to Passenger Transport

\begin{tabular}{|l|l|c|c|}
\hline No & Variable & $\begin{array}{c}\text { Mean } \\
\text { Importance }\end{array}$ & $\begin{array}{c}\text { Mean } \\
\text { Performance }\end{array}$ \\
\hline
\end{tabular}




\begin{tabular}{|c|l|l|l|}
1 & $\begin{array}{l}\text { Other Port Terminal facilities have met } \\
\text { expectations (such as: toilets, waiting rooms, } \\
\text { praying rooms, kiosks, temperature control } \\
\text { facilities (AC.fans) and others) }\end{array}$ & 455 & 183 \\
\hline 2 & $\begin{array}{l}\text { The port terminal provides information on the } \\
\text { availability of emergency rescue equipment in } \\
\text { danger (fire, accident or natural disaster) and } \\
\text { health facilities for emergency treatment }\end{array}$ & 403 & 317 \\
\hline 3 & $\begin{array}{l}\text { Bolok Crossing Harbor Terminal provides } \\
\text { information conveyed inside the terminal to } \\
\text { service users regarding estimated time of arrival } \\
\text { and departure of the ship }\end{array}$ & 414 & 316 \\
\hline 4 & $\begin{array}{l}\text { The Port Terminal Officer gives you good service } \\
\text { if there are problems with the Terminal facilities }\end{array}$ & 385 & 386 \\
\hline 5 & The port terminal has applicable regulations & 443 & 384 \\
\hline 6 & $\begin{array}{l}\text { The port terminal is always under the supervision } \\
\text { of internal parties (security officers) }\end{array}$ & 391 & 388 \\
\hline 7 & $\begin{array}{l}\text { The Port Terminal has good and effective parking } \\
\text { regulations to create a smooth flow }\end{array}$ & 434 & 424 \\
\hline
\end{tabular}

Figure 2. Importance-Performance Analysis (IPA) Diagram Results by Transportation Crew (Driver)

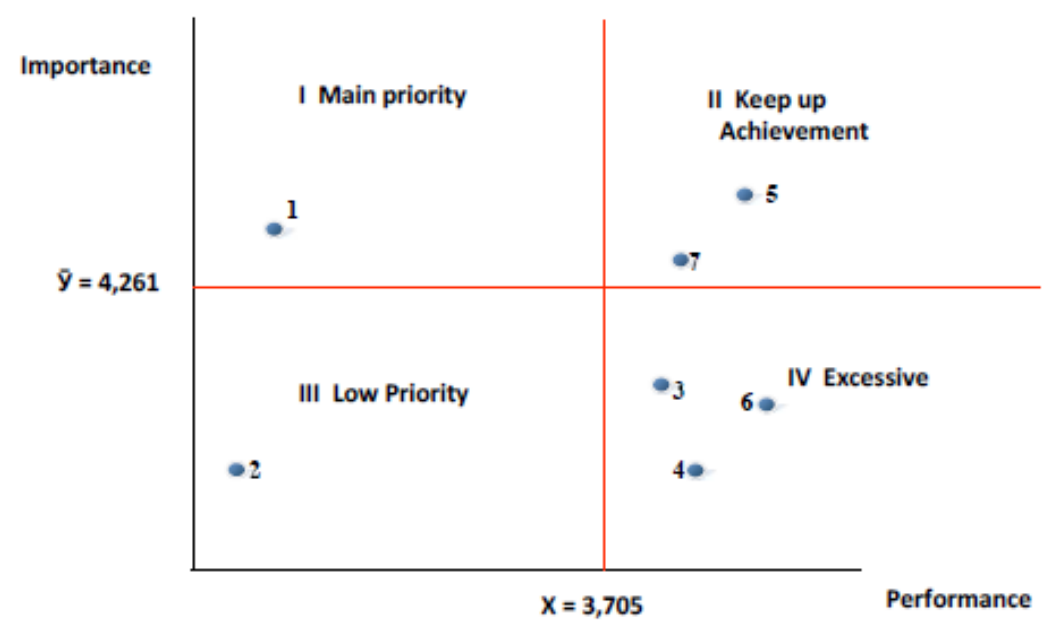

The explanation for each quadrant is as follows:

I. First Quadrant (main priority)

There is one factor that is located in this quadrant, that is the other Port Terminal Facilities, they have met expectations (such as: toilets, waiting rooms, praying rooms, kiosks, air conditioning facilities, fans and others). This means that port terminal service users are not satisfied with the service of the factors, thus demanding an effort to improve service quality.

Other Port Terminal Facilities have not met expectations (such as toilets, waiting rooms, praying rooms, kiosks, air conditioning facilities, fans, etc.) because the waiting rooms and toilets that available at Bolok terminal port are not comfortable because they look unclean, 
and passenger waiting rooms when in crowded conditions, many passengers sit on the floor because they do not get a seat.

II. Second Quadrant (keep up achievement)

There are 2 factors of port terminal service that successfully occupy this quadrant namely port terminals have applicable regulations and port terminals have good and effective parking regulations to create a smooth flow. According to respondents, the Port Terminal has regulations that are in place where regulations are mandatory to be carried out while at the port so that the community feels more comfortable when at the port. The Port Terminal has good and effective parking regulations to realize a smooth flow according to respondents in the existing parking terminals that are good, so far the traffic flow is smooth and there is no traffic jam.

III. Third Quadrant (low priority)

There is one factor in port terminal services that occupies this quadrant and has low priority to be carried out, namely that the port terminal provides information on the availability of emergency rescue equipment in danger (fire, accident or natural disaster) and health facilities for emergency treatment. according to respondents they paid less attention to these factors.

IV. Fourth Quadrant (excessive)

There are three factors that get over-assessment from respondents, namely Bolok Crossing Harbor Terminal provides information delivered in the terminal to the service user regarding estimated time of arrival and departure of the ship, the Port Terminal Officer gives you good service if there are problems with the Terminal facilities and the Port Terminal always under the supervision of internal parties (security officers). According to respondents there is always information about the arrival and departure of the ship, both when the ship that wants to be boarded does not depart according to the specified schedule, this information is obtained from the local location and also some social media so that respondents who want to pick up passengers to the port do not have to come to the port. And according to respondents so far there are always security officers who are always on guard to maintain the security and comfort that is in the port at the port.

\subsection{Terminal Services User Satisfaction (Customer Satisfication Index) a) Port Terminal Passenger Satisfaction}

The results of the analysis of respondents' answers to eight indicators / attributes of terminal services by interpreting the value of the Customer Satisfication Index showed that the services provided by terminal managers are quite good, but terminal service users are not satisfied with the factors of other port terminal facilities that haven't met expectations (such as: toilets, space wait, prayer rooms, kiosks, air conditioning facilities, fans, etc.). This assessment is based on the lack of terminal facilities in the waiting room in the absence of health service rooms, designated smoking areas, praying room for the moslems and temperature control facilities as well as passengers feeling uncomfortable with a less clean waiting room atmosphere.

\section{b) Satisfaction of the Port Terminal Driver}

The results of the analysis of respondents' answers to the seven indicators / attributes of terminal services by interpreting the value of the Customer Satisfication Index showed that the services provided by terminal managers are quite good, but terminal service users are not satisfied with the factors of other port terminal facilities that have met expectations (such as: toilets, space wait, praying rooms, kiosks, air conditioning facilities, fans, etc.). This assessment is based on the lack of terminal facilities in the waiting room in the absence of health service rooms, designated smoking areas, places of worship and temperature control 
facilities as well as passengers feeling uncomfortable with a less clean waiting room atmosphere

\section{Conclusion}

1. Factors affecting service user ratings of services at the crossing port terminal for passenger service users are other port terminal facilities factors that have met expectations (such as: toilets, waiting rooms, praying rooms, kiosks, AC temperature control facilities, fans, etc.) in quadrant I. These factors are considered important while in terms of satisfaction, service users feel dissatisfied, so that demand for improvement in service quality is a top priority by service providers

2. Factors that influence the assessment of service users towards services at the crossing port terminal for the transport crew service user (driver) are other port terminal facilities factors that have met expectations (such as: toilets, waiting rooms, praying rooms, kiosks, air conditioning temperature control facilities, fan and others) in quadrant I. These factors are considered important while in terms of satisfaction, service users feel dissatisfied so that demand for improvement in service quality is a top priority by service providers.

3. Perceptions of service users (passengers) of the Bolok port terminal based on an average satisfaction index value of 8 (eight) service factors of 87.8 percent are included as very satisfied criteria. other port terminal facilities have met expectations (such as: toilets, waiting rooms, prayer rooms, kiosks, air conditioning facilities, fans, etc.) are less satisfied and become the main priority for performance by the terminal manager.

4. The service user perception (transport crew / driver) of the Bolok port terminal is based on an average satisfaction index value of 7 (seven) service factors of 85.86 percent in the very satisfied criteria. other port terminal facilities have met expectations (such as: toilets, waiting rooms, prayer rooms, kiosks, air conditioning facilities, fans, etc.) are less satisfied and become the main priority to be noticed by the terminal manager.

\section{References}

[1] Azwar Saifudin, 2003, Reliabilitas dan Validitas, Pustaka Pelajar Offset, Yogyakarta

[2] Peraturan Pemerintah No.69 Tahun 2001 Pasal 1 ayat 1, tentang Kepelabuhanan

[3] Tuati, Anie, 2013, Kajian Teknis Pelayanan Terminal Bus Oebobo, Kupang - Nusa Tenggara Timur, Tesis Magister, Program Magister Teknik Sipil Transportasi, Universitas Atma Jaya Yogyakrata.

[4] Suparmoko, M., 1991, Metode Penelitian Praktis, BPFE-Yogyakarta

[5] Triatmodjo, Bambang; 1996, Pelabuhan, Beta Offset, Yogyakarta.

[6] Warpani, Suwadjoko P., 2002, Lalu Lintas dan Angkutan Jalan, ITB, Bandung

[7] Undang-Undang Republik Indonesia No.17 Tahun 2008, tentang Pelayaran

[8] Peraturan Mentri Perhubungan Republik Indonesia No. 37 Tahun 2015 tentang standar pelayanan penumpang angkutan laut

[9] Pramesti G, 2013, Smart Olah Data Penelitian dengan SPSS 21, Elex Media Komputindo, Jakarta.

[10] Soamole, Budiman, 2013, Analisis Persepsi Penumpang terhadap Kualitas Pelayanan 
Angkutan Laut di Pelabuhan Regional Sanana Kabupaten Kepulauan Sula Provinsi Maluku Utara, Tesis Magister, Program Magister Teknik Sipil Transportasi, Universitas Atma Jaya Yogyakrata.

[11] Mulatsi Retno, Wahyudi Edi, dan Sumantri Sri Andar. 2018. Manajemen Kualitas Pelayanan Transportasi Laut dalam Meningkatkan kepuasan Pelanggan Pada Jasa Bongkar Muat. Jurnal Organisasi dan Manajemen. 14(2).

[12] Martila A. John and James C, Jhon, 1997. The Analysis of Importance and Satisfaction level of the Customers. Prentice Hall Inc

[13] Sedarmayanti, 2011, Metode Penelitian, CV. Mandar Maju, Bandung 